\title{
A Theoretical Study: The Flipped Classroom Model As An Effective And Meaningful Learning Model In Multiple Era
}

Suhartono, Institut Agama Islam Pangeran Diponegoro Nganjuk. Email: suhartono@iaipd-nganjuk.ac.id

Suherman, University of Szeged, Hungary, Email : suherman@edu.u-szeged.hu

Pitersina. Ch. Lumamuly, Institut Agama Kristen Negeri ( Iakn) Ambon, Email : pchlumamuly@gmail.com

Novita Loma Sahertian, Institut Agama Kristen Negeri ( Iakn) Ambon, Email : vitasahertian@gmail.com

Lourine Since Joseph, Institut Agama Kristen Negeri ( Iakn) Ambon, Email : lourinejoseph919@gmail.com

Rukhama Aralaha, Institut Agama Kristen Negeri ( Iakn) Ambon, Email : raralaha67@gmail.com

Yowelna Tarumasely, Institut Agama Kristen Negeri ( Iakn) Ambon, Email : yowelnatarumasely@gmail.com

Suheri, Sekolah Tinggi Agama Islam At-Taqwa Bondowoso. Email: suheri.lpdp@gmail.com

\begin{abstract}
This article aims to describe the flipped classroom model as an effective and meaningful learning model in various times. The flipped classroom model (flipped model) is a learning model that emphasizes learning in the classroom and outside the classroom, where conventional activities are carried out in class into activities at home, and activities carried out at home become activities in class. The flipped classroom model makes learning effective with active student involvement in the learning process, and meaningful learning with the influence of better changes in cognitive, affective, and skill aspects in students. The flipped classroom model is closely related to a more efficient use of learning time, where outside the classroom (at home) students have studied material and done assignments, then in class problem solving is carried out by discussing and completing assignments/ evaluations given by the teacher. Assessment in the flipped classroom model with comprehensive and authentic assessment, comprehensive assessment, namely the learning process and results. The flipped classroom model can be applied at any time, regardless of any conditions, wherever there is a learning process and using digital technology / information technology that is developing in the current era.
\end{abstract}

Keywords:

flipped classroom model, effective learning, meaningful

Article Received: 18 October 2020, Revised: 3 November 2020, Accepted: 24 December 2020

Correspondent author : Suheri, Email Suheri.lpdp@gmail.com

\section{A. INTRODUCTION}

The learning process is a reflection of the success and failure of achieving educational goals. The main goal of education is to help students become independent individuals and be able to organize themselves (Arends, 2013). This means, with education there will be changes in the quality of students themselves, both changes in skills, personality, and skills of students, so that students are able to manage their own lives. Learning is the process of developing knowledge, skills or attitudes as an individual's interaction with their environment (Heinich, 1999). By learning, students will get changes in cognitive, psychomotor, and affective aspects (Spector, 2012; Kasilingam, Ramalingam, \& Chinnavan, 2014).

Learning is a process of linking new knowledge to cognitive structures that are already owned by students (Degeng, 2013). Learning as a process creates a relationship between the knowledge that students already understand and the knowledge they have just acquired. Degeng (2013) states that learning is influenced by learning. The learning 
process will be effective, if the learning process is student centered, so that students actively participate in the learning process (Suhartono, Degeng, Suyitno, \& Sulton, 2019; Unin \& Bearing, 2016).

Effective learning requires flexibility, creativity, and responsibility to provide a learning environment that can meet the individual needs of students (Tulbure, 2012). Slavin (2017), effective learning indicators include (1) the quality of teaching related to the presentation of information or the ability of learners to help students learn lesson material easily, (2) the right level of teaching is related to the ability of teachers to ensure the accuracy of subject matter against student abilities , (3) incentives related to the ability of teachers to ensure student motivation in learning, and (4) learning time related to providing sufficient time for students to study the subject matter being taught. In learning, students should be given the opportunity to develop their abilities by referring to the indicators of effective learning, so that learning can provide meaning to students in learning.

The meaning of learning is the result of learning which is marked by the relationship between new aspects, concepts, information or situations and the relevant components in the cognitive structure of students (Novak, 2011). Meaningful learning is also a reflection in the context of $21 \mathrm{st}$ century learning which demands learning that can produce human resources who are able to think critically, are able to solve problems, are useful for the future (Jansen \& Merwe, 2015). Therefore, teachers must be able to create an effective classroom atmosphere, activate students to develop their potential, and perfect the learning process for students (Arends, 2013). With effective learning that can provide meaningful learning to students, it is a reflection of the quality of learning which is very important for student self change in its cognitive, affective, and psychomotor aspects. Through this approach, students are expected to have far better competence in attitudes, skills and knowledge (Wahyudi \& Suheri, 2020).

As the Covid-19 pandemic has spread throughout the world, including Indonesia, it has changed the learning process in the classroom to switch to learning at home with an online learning system. In this learning system, the teacher provides learning materials and assignments in various forms such as videos, e-book files, and so on. In the new order period recently, the learning process has been allowed for face to face learning with a limited time scale and a rotating schedule. To maximize learning, one solution is to apply the flipped classroom model. This model also shows a graph that is increasing in recent studies (Hwang, Yin, \& Chu, 2019).

The flipped classroom model is a learning model that has been applied in learning in various fields of study at schools and colleges around the world (Shyr dan Chen, 2018). In the learning process, not only in class, but at home there is also a learning process with various materials and assignments from the teacher. The teacher provides materials and assignments as well as monitors student activities at home learning with various digital media applications that are currently developing, such as wathshap, google zoom, google classroom, and so on.

The application of the flipped learning model (flipped classroom) cannot be separated from the use of digital technology. The development of digital technology in the current Industry 4.0 era has had a significant influence on learning by adapting and using technology in the current era (Ghiffar, Nurisma, Kurniasih, \& Bhakti, 2018), to face the industrial revolution 4.0. The development of science and technology penetrated into all sectors of life (Nasih et al., 2020) because digital technology-based learning offers effectiveness, efficiency and attractiveness (Hoyles \& Lagrange, 2010), as well as facilitate learning and improve student performance (Januszewski \& Molenda, 2008). One example, students have used a lot of Android mobile media with various features in learning. In this media can access various knowledge and information. Digital technology can support the achievement of learning goals and develop the potential that exists in students.

The flipped learning model (flipped classroom) is an effective and meaningful learning model for significant changes in aspects of knowledge, attitudes, and skills in students. Several research results have shown that there is a significant effect of the 
application of the flipped learning model (flipped classroom) on student learning outcomes (cognitive, affective, and psychomotor).

Several research results are related to the effectiveness and meaning of the flipped learning model (flipped classroom) in the learning process and learning outcomes, including the results of research stating that the flipped classroom model makes students active (Davies, Dean, \& Ball, 2013; Clarisa, Danawan, Muslim, \& Wijaya, 2020); creating active learning (Siegle, 2013; Ozdamli \& Asiksoy, 2016; Heinerichs, Pazzaglia, \& Gilboy, 2016); increasing student independence (Lo \& Hew, 2017; Sun, Wu, \& Lee, 2017; Yamada, Shimada, Okubo, Oi, Kojima, \& Ogata, 2017); improve creative attitudes (Laman, Brannon, \& Mena, 2012; Damayanti \& Sutama, 2016), responsibility (Laman, Brannon, \& Mena, 2012; Lai \& Hwang, 2016; Damayanti \& Sutama, 2016), and student skills (Damayanti \& Sutama, 2016); developing higher order thinking skills (Lai \& Hwang, 2016); and improve learning achievement (Lambert, 2012; Midun, Degeng, Kuswandi, \& Ulfa, 2019).

There are still a lot of research results regarding the application of the flipped classroom model, but some of the research results above are able to answer that the flipped classroom model is an effective and meaningful learning model in achieving learning objectives. For that, it is necessary to understand in depth about what the flipped classroom learning model is and how to implement it.

\section{B. DISCUSSION}

\section{Definition of the Flipped Classroom Model}

The term flipped classroom in various literatures is different, such as "flipping classroom", "flipped classroom", "flipped learning", "reserved instruction", and "inverted classroom" (Çetinkaya, 2017). Flipped Classroom has the meaning of reversing the class (Strayer, 2012). Flipped classroom is a learning model that reverses learning activities in class. Lage, Platt, \& Treglia (2000) explain that "Reversing the class" means events that traditionally occur in the classroom now take place outside the classroom and vice versa. Bergmann \& Sams
(2012) explain that the flipped classroom is a learning model that applies an inverted concept, where conventional activities carried out in class (for example, giving material) become activities at home, and activities carried out at home such as homework become activities carried out in class. This means that activities in a flipped classroom are learning activities that are usually carried out in class which are transferred to be carried out at home and learning assignments at home are done and completed in class.

The inverted classroom model (flipped classroom) is a pedagogical effort by learners to create active learning through a "reverse" procedure from learning in traditional classrooms using media and appropriate learning resources (Midun, Degeng, Kuswandi, \& Ulfa, 2019). Flipped classroom model, students get learning not only in class, but outside the classroom. Outside the classroom, students are asked to find and study learning resources about the material to be studied, then in the classroom, students try to apply the knowledge they have acquired by solving problems or assignments given by students (Faqih, Sulthon, \& Ulfa, 2016). Bishop \& Verleger (2013) defines a flipped classroom as a student-centered learning model consisting of two parts with interactive learning activities during classroom learning and individual learning directly on the computer outside of class hours. Ozdamli \& Asiksoy (2016) defines a simpler flipped classroom model, that what is done in class is done at home and what is done at home is done in class.

The flipped classroom model can be defined as a learning model whose application reverses the learning process, where the teacher delivers material and learning assignments to do at home and when face to face in class discussions are held to solve problems.

\section{Characteristics of the Flipped Classroom} Model

The flipped classroom model is a learning model that maximizes time for learning and learning for students in class and at home, minimizes direct instruction by teachers to students in teaching subject matter, and maximizes time for students to interact and discuss in solving learning 
problems/ tasks.

Abeysekera dan Dawson (2015) mention the characteristics of the flipped classroom model, including (1) changes in the use of time in class, (2) changes in the use of time outside of class, (3) doing activities that are traditionally considered 'homework' in the classroom, (4) doing activities that are traditionally considered work in the classroom outside the classroom, (5) activities in class that emphasize active learning; peer learning; problem solving, (6) pre class activities, (7) post class activities, and (8) use of technology, especially video.

The characteristics of the flipped classroom model are closely related to the use of time, learning activities carried out inside and outside the classroom, and the use of digital technology that is currently developing.

3. Components in the Flipped Classroom Model

Anderson \& Krathwohl (2001; 2010) suggest that in the flipped classroom model there are several components, including (1) providing opportunities for students to get their first exposure before learning in class. The mechanisms used to study at home can vary, from textbooks, teaching materials, or learning videos or other similar resources that do not have to be high tech, students only complete pre class reading assignments, (2) provide more time for students to prepare materials before attending the learning process in the classroom, (3) providing procedures or procedures for assessing students' understanding of knowledge. Pre class assignments are students completing material that must be read before class begins. To find out and assess student preparation, the teacher makes pre class worksheets. Of particular importance are sufficient time in class for discussion between students, thereby reducing the role of the teacher, and (4) classroom activities that focus on higher level cognitive activities. Where student activities in class are discussion, data analysis, or synthesis activities. The key is that students use class time to deepen their understanding and improve skills.

\section{Steps for the Flipped Classroom Model}

The application of the flipped classroom learning model is essentially to enable students to learn and absorb knowledge independently, then deepen their understanding in the classroom (Smith \& Mcdonald, 2013). The flipped classroom model in learning is carried out by providing teaching materials and assignments to students to be studied and done at home. Furthermore, when learning in class is carried out discussions to solve problems and solve test questions given by the teacher, so that students will be more active and interactive in the learning process. Bergmann \& Sams (2012) states that learning with the flipped classroom model, students learn lesson material at home by watching learning videos, summarizing, writing important points, making discussion questions with friends and reading the needed resources, then doing assignments, and (Strayer, 2012) can also discuss and listen to explanations of concepts that students have not understood to strengthen subject matter in class.

Bergmann \& Sams (2012); Johnson (2013); Faqih, Sulthon, \& Saida Ulfa (2016) states the steps for the flipped classroom model as follows:

1) Before face to face, the teacher asks students to study independently at home about the material for the next meeting, by finding and studying learning resources in the form of books, articles, learning videos and others.

2) In classroom learning, the teacher divides students into small groups (heterogeneous).

3) When the learning process takes place, the teacher facilitates the discussion and prepares several questions (questions) from the learning material.

4) The teacher provides quizzes/ tests and helps students in learning and completing questions related to learning material.

The steps of the flipped classroom model implementing the learning and learning process include (1) activities at home (outside the classroom), students study material and do assignments at home independently; (2) activities in the class include (a) the teacher conditions the class and divides students into groups, (b) students conduct discussions to solve problems and complete assignments, (c) present work results, and (d) conduct evaluations.

5. Strengths and Weaknesses of The Flipped Classroom Model

Each learning model has advantages and disadvantages. Likewise, the flipped 
classroom model also has advantages and disadvantages. According to Bergmann \& Sams (2012), the advantages of the flipped classroom learning model are (1) following the development of students according to their times, (2) helping students who are busy, (3) helping students with difficulties, (4) helping students with the ability to understand the material weak, (5) allows stopping and repeating the teacher's explanation via video, (6) increasing the interaction between teachers and students, (7) enabling teachers to recognize students better, (8) increasing interaction between students and students, (9) improving classroom management, (10) changing the way students interact with parents, (11) making classrooms transparent, and (12) good techniques for absent teachers.

Berrett (2012) mentions the advantages of the flipped classroom model, including:

a. For student

1) students have sufficient time to study subject matter at home.

2) students can learn subject matter in comfortable conditions and atmosphere by receiving material according to their abilities.

3) students get full attention from the teacher when they have difficulty understanding the material, assignments or exercises.

4) students can learn from various types of learning content, either through videos / books / teaching materials / websites

b. For teachers

1) More effectively, the material is presented in various forms of video / e book that can be used repeatedly in other classes.

2) Save time, the teacher does not have to explain all the subject matter, but only certain parts that are considered difficult by students.

3) Teachers are motivated to prepare subject matter in various types of content, whether in the form of videos, websites, mobile applications or other types of content.

4) Teachers are increasingly creative in making learning modules that use digital technology that makes it easier for students to understand concepts.

5) There is active communication between teachers and students, where in class learning there is more discussion (question and answer) between them.

Berrett (2012) also mentions the weaknesses of the flipped classroom model, including:

a. Not all teachers/ students/ schools have access to the necessary digital technology devices, such as computers/ laptops and an internet connection.

b. Not all students feel comfortable learning in front of a computer/ laptop, where in the implementation of the flipped classroom model, students must access the material through the device.

c. Not all students have the motivation to study independently at home, especially the material that has not been delivered by the teacher.

6. Application of the Flipped Classroom Model in Learning

Learning is the teacher's effort to teach subject matter to students. The efforts made by the teacher include making lesson plans, implementing learning, and providing learning evaluations.

In relation to the design of implementing the flipped classroom model in learning, it can be described as follows:

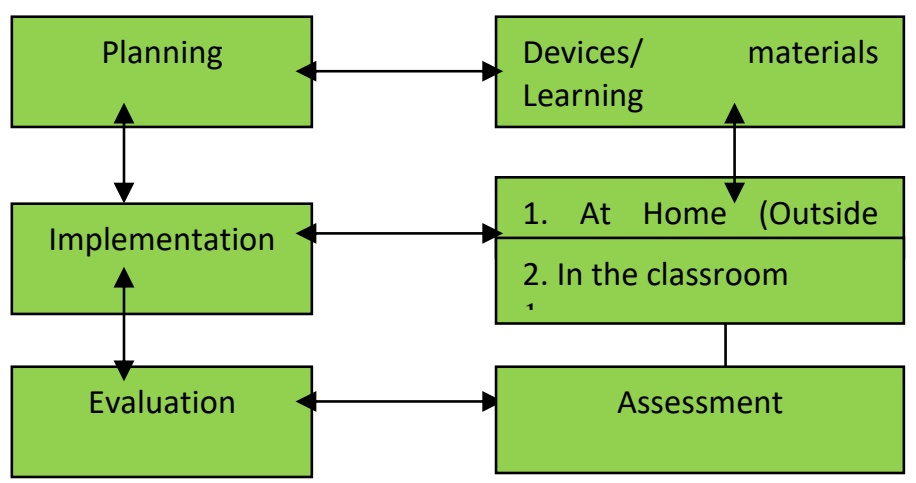

The design of the application of the flipped classroom model in the learning above, includes three stages of activity including planning, implementing, and providing evaluation which can be described as follows:

1. Planning the application of the flipped classroom model in learning

Planning is an activity to determine what will be done. Learning planning as a critical success factor in the learning process. Learning planning that is packaged properly and carefully, then the implementation of 
learning will be directed and facilitate the achievement of learning objectives.

In the planning stage, the teacher prepares learning tools in the form of a syllabus, learning implementation plan, learning media, student worksheets, and evaluation and assessment instruments. In addition, the teacher also prepare teaching materials that can be made in the form of instructional videos, power points, e book, and so on. Learning planning is designed in the form of a syllabus and lesson plan which refers to the content standard. Learning planning includes the preparation of a learning implementation plan and preparation of media and learning resources, learning assessment tools, and learning scenarios (Directorate General of Islamic Education, 2019).

Teaching materials and student worksheets are distributed by the teacher to students at the end of the lesson and online through networks that are easily accessible to students such as Facebook, Share It, Whatsapp, Bluetooth, and so on.

2. Implementation of the flipped classroom model in learning

The concept of implementing the flipped classroom model can be described as follows:

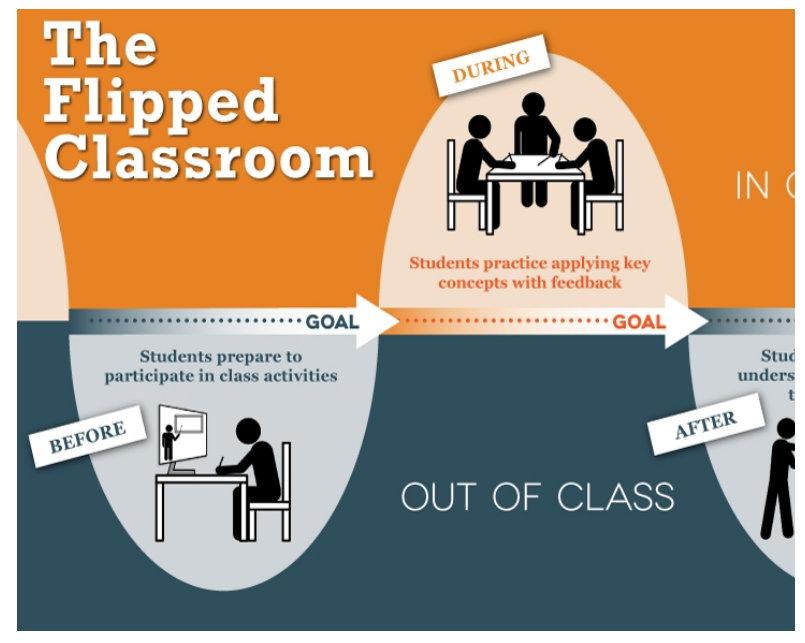

Figure 1: The concept of implementing the Flipped Classroom (literasidigital.com in Hastuti, 2020)

The concept of implementing the flipped classroom model above is related to Bloom's taxonomy which is described below:

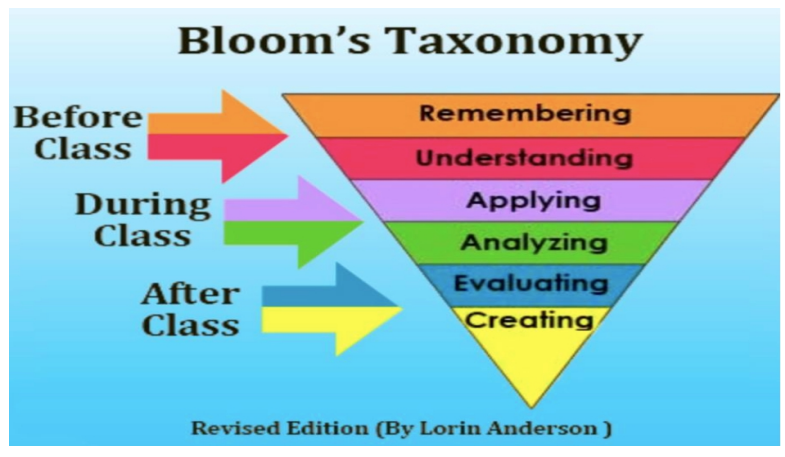

Figure 2: The relationship between Bloom's taxonomy and the flipped classroom model (Hastuti, 2020)

The concept of the flipped classroom model is divided into three stages of activity, namely (1) activities before the class begins (pre-class), students learn the material to be discussed so that students have the ability to remember (remembering) and understand (understanding) the material; (2) in-class activities, students can apply and analyze (analyzing) material by interactive activities or discussing in class; and (3) after class activities (out of class), students evaluate (evaluating) and complete assignments / projects (creating).

Implementation of learning is the process of implementing a Learning Implementation Plan (RPP). The implementation of the flipped classroom model in learning is carried out outside the classroom (home) and inside the classroom. Referring to the steps of the flipped classroom model, the implementation of the flipped classroom model in learning can be developed as follows:

a. Implementation of learning outside the classroom (home)

1) Students study teaching materials (videos, ebooks, or others) and do assignments that have been distributed by the teacher.

2) Students prepare assignments independently as well as possible.

3) The teacher monitors students in the learning process at home with Whatsapp groups or others.

b. The implementation of learning in the classroom consists of initial, core, and final activities.

1) Initial activities

a) The teacher conditions the class

b) The teacher motivates students about the importance of learning material. 
c) The teacher conveys the learning objectives

2) Core activities

a) The teacher divides students into several groups

b) Students hold discussions in groups

c) The teacher observes and facilitates the group discussion process

d) Students present the results of the discussion

e) The teacher provides practice questions/ evaluation

3) Final activity

a) Teachers and students make conclusions

b) The teacher gives assignments for the next lesson.

c. Evaluation on the application of the flipped classroom model in learning

Evaluation comes from English with the word "evaluation" which means assessment or assessment (Echols and Shadily, 1996). Evaluation is a process to assess the quality of something that is on going (Kaufman \& Thomas, 1980), and is used to consider decisions in the assessment of an achievement (Pophan, 1987). Evaluation or appraisal leads to determining the value of quality or achievement of something done.

In evaluation or assessment, it is necessary to develop an assessment system that is able to measure the overall ability of students as learning outcomes and encourage students to develop all their potential (Absari, Sudiana, \& Wendra, 2015). An effective and efficient evaluation or assessment is carried out comprehensively, so that teachers can get a complete picture of the learning achievements and results achieved by students in learning. Likewise, the evaluation or assessment carried out in the flipped classroom model is a comprehensive assessment. The results of research by Zhou \& Jiang (2014) state that comprehensive assessment is an inseparable part of the flipped classroom model, this activity includes assessment of the understanding process, the application process, and analysis through presentation activities, learning outcomes reports, and self evaluation. Comprehensive assessment includes assessment of learning processes and outcomes which can be called authentic assessment.
Authentic assessment is complex and comprehensive (Absari, Sudiana, \& Wendra, 2015). Assessment is not only carried out at the end of the competency, but is carried out during the learning process. Authentic assessment is an assessment to measure, monitor and assess all aspects of learning outcomes (cognitive, affective, and psychomotor) during the learning process in the classroom and outside the classroom.

Authentic assessment is significantly more significant for learning outcomes. Types of authentic assessment consist of nine types, namely performance, assessment of observations, projects and investigations, diaries, journals, interviews and conferences, open response questions, self and peer assessments, and portfolios (Atmazaki, 2013). Authentic assessment is a measure that has a significant meaning in the aspects of student knowledge, attitudes, and skills.

\section{CONCLUSION}

The flipped classroom model is a learning model that emphasizes learning inside and outside the classroom. This learning model applies the concept of flipping, where conventional activities carried out in class become activities at home, and activities carried out at home become activities in class. Many research results state that the flipped classroom model makes learning effective with active student involvement in the learning process, and meaningful learning with the influence of better changes in cognitive, affective, and skill aspects in students.

The flipped classroom model is closely related to a more efficient use of learning time, where outside the classroom (at home) students have studied material and done assignments, then in class problem solving is carried out by discussing and completing assignments/ evaluations given by the teacher. The assessment in the flipped classroom model also includes a comprehensive and authentic assessment. Assessment is not only on the final result of learning, but also during the learning process.

The flipped classroom model can be applied at any time and does not recognize any conditions. This learning model does not limit learning only in class, but wherever it 
can be used for learning. In addition, this learning model also uses digital technology/ information technology that is developing in the current era, so that students can develop their various potentials.

\section{References}

[1] Absari, I.G.A.K.L., Sudiana, I. N., Wendra, I.W.(2015). Penilaian Autentik Guru Bahasa Indonesia dalam Pembelajaran Menulis Siswa Kelas VII di SMP Negeri 1 Singaraja. eJournal Universitas Pendidikan Ganesha Jurusan Pendidikan Bahasa dan Sastra Indonesia, 3 (1), 1-10.

[2] Abeysekera, Lakmal and Dawson, Phillip .(2015). Motivation and cognitive load in the flipped classroom : definition, rationale and a call for research, Higher education research \& development, 34(1), 1-14.

[3] Anderson, L. W., \& Krathwohl, D. R. (2001). Taxonomy for Learning, Teaching and Assessing: A Revision of Bloom's Taxonomy of Educational Objectives. New York: Longman.

[4] Anderson, L., \& Krathwohl, D. (2010). Kerangka Landasan Untuk Pembelajaran, Pengajaran, dan Assesmen. Diterjemahkan Agung Prihantoro. Yogyakarta: Pustaka Belajar.

[5] Arends, R. I. (2013). Belajar untuk Mengajar; Learning to Teach $9^{\text {th }}$. Diterjemahkan Made Frida Yulia. Jakarta: Salemba Humanika.

[6] Atmazaki. (2013). Implementasi Kurikulum 2013 Mata Pelajaran Bahasa Indonesia: Pola Pikir, Pendekatan Ilmiah, Teks (Genre), dan Penilaian Otentik. Proceeding of the International Seminar on Languages and Arts.

[7] Berrett, D. (2012). How 'flipping' the classroom can improve the traditional lecture. The Chronicle of Higher Education, 12(19), $1-3$.

[8] Bergmann, J. and Sams, A. (2012). Flip Your Classroom : Reach Every Student in Every Class Every Day. United States: The International Society For Technology In Education.

[9] Bishop, J. L., \& Verleger, M. A. (2013). The flipped classroom: A survey of the research.
In ASEE National Conference Proceedings, Atlanta, GA, 30(9), 1-18.

[10]Clarisa, G., Danawan, A., Muslim, \& Wijaya, A.F.C. (2020). Penerapan Flipped Classroom dalam Konteks ESD untuk Meningkatkan Kemampuan Kognitif dan Membangun Sustainability Awareness Siswa. JNSI: Journal of Natural Science and Integration, 3(1), 13-25.

[11] Damayanti, H. N., \& Sutama, S. (2016). Efektivitas flipped classroom terhadap sikap dan ketrampilan belajar matematika di SMK. Manajemen Pendidikan, 11(1), 2-7.

[12] Davies, R. S., Dean, D. L., \& Ball, N. (2013). Flipping the classroom and instructional technology integration in a college-level information systems spreadsheet course. Educational Technology Research and Development, 61(4), 563-580.

[13] Degeng, I. Nyoman S. (2013). Ilmu Pembelajaran: Klasifikasi Variabel Untuk Pengembangan Teori dan Penelitian. Bandung: Aras Media.

[14] Direktorat Jenderal Pendidikan Islam. (2019). Keputusan Menteri Agama Republik Indonesia Nomor 183 Tahun 2019 Tentang Kurikulum Pendidikan Agama Islam Dan Bahasa Arab Pada Madrasah, Jakarta: Kementerian Agama RI.

[15] Echols, John M. \& Shadily, Hasan. (1996). Kamus Inggris Indonesia, Jakarta: Gramedia.

[16] Faqih, W.F., Sulthon, \& Ulfa, S. (2016). Meningkatkan Keaktifan Peserta Didik dalam Pembelajaran Sejarah dengan Model Flipped Classroom. Prosiding UM: Inovasi Pendidikan di Era Big Data dan Aspek Psikologinya, 523-528.

[17] Ghiffar, M.A.N., Nurisma, E., Kurniasih, C., \& Bhakti, C. (2018). Model Pembelajaran Berbasis Blended Learning Dalam Meningkatkan Critical Thinking Skills Untuk Menghadapi Era Revolusi Industri 4.0. Prosiding Seminar Nasional Pendidikan, STKIP Andi Matappa Pangkep, 85-94.

[18] Hastuti, Wiwik Dwi. (2020). Bab XII Membangun Motivasi dan Kemandirian Peserta Didik Berkebutuhan Khusus Melalui Flipped Classroom di Masa New Normal Covid-19. Prosiding Webinar Magister Pendidikan Nonformal Pascasarjana 
Universitas Negeri Gorontalo; Tema: Pembelajaran Anak Usia Dini berbasis Sentra Alam dengan Pendekatan Saintifik pada Masyarakat Teluk Tomini Gorontalo, 8 September 2020, 181-192.

[19] Heinich, Robert, et.al. (1999). Instructional Media and Technology for Learning, New Jersey: Prentice Hall.

[20] Herreid, C.F., \& Schiller, N.A. (2013). Case studies and the flipped classroom. Journal of College Science Teaching, 42(5), 62-66.

[21] Hoyles, C., \& Lagrange, J.-B. (Eds.). (2010). Mathematics education and technology-Rethinking the terrain. New York, NY/Berlin, Germany: Springer.

[22] Hwang, G.J., Yin, C., \& Chu, H.C. (2019). The era of flipped learning: promoting active learning and higher order thinking with innovative flipped learning strategies and supporting systems. Interactive Learning Environments, 27(8), 991-994.

[23] Jansen, C. \& Merwe, P. (2015). Teaching practice in the 21st century: Emerging trends, challenges and opportunities. Universal Journal of Educational Research, 3(3), 190199.

[24] Januszewski, A. \& Molenda, M. (Eds.) (2008) Educational technology: A definition with commentary. New York: Lawrence Erlbaum Associate.

[25] J.D., Novak. (2011). A theory of education: meaningful learning underlies the constructive integration of thinking, feeling, and acting leading to empowerment for commitment and responsibility. Meaningful Learning Review, 1(2), 1-14.

[26] Johnson, Graham Brent. (2013). Student Perceptions of The Flipped Classroom. Columbia: The University of British Columbia.

[27] Kasilingam, G., Ramalingam, M., \& Chinnavan, E., (2014). Assessment of Learning Domains to Improve Student's Learning in Higher Education. Journal of Young Pharmacists, 6(4), 27-33. doi: $\underline{10.5530 / j y p .2014 .1 .5}$

[28] Kaufman, R., \& Thomas, S. (1980). Evaluation without fear. New York: New Viewpoints.
[29] Lage, Maureen J., Platt, Glenn J., and Treglia, Michael. (2000). "Inverting the classroom: A gateway to creating an inclusive learning environment." The Journal of Economic Education, 31 (1), 30-43.

[30] Lai, C.L., \& Hwang, G.J. (2016). A selfregulated flipped classroom approach to improving students' learning performance in a mathematics course. Computers \& Education, $100,126-140$.

[31] Lambert, C. (2012). Twilight of the Lecture. Harvard Magazine, 114(4), 23-27.

[32] Lo, C. K., \& Hew, K. F. (2017). A critical review of flipped classroom challenges in $\mathrm{K}$ 12 education: possible solutions and recommendations for future research. Research and Practice in Technology Enhanced Learning, 12(1), 4. https://doi.org/10.1186/s41039- 016-0044-2.

[33] Midun, H., Degeng, I.N.S., Kuswandi, D., \& Ulfa, S. (2019). Effects of Inverted Classroom and Self-Regulated Learning on Conceptual Learning. International Journal of Innovation, Creativity and Change, 8,(2), 181-201.

[34] Nasih, A. M., Hamid, A., Yani, A., Suheri, Sultoni, A., \& Harnadi, D. (2020). The Use and Development of Seamless Learning Strategy for Islamic Education Course in Indonesian Higher Education. 492(RIICMuSSS 2019), 79-83. https://doi.org/10.2991/assehr.k.201113.015

[35] Ozdamli, F \& Asikoy, G. (2016). Flipped Classroom Approach. World Journal on Education Technology, 8 (2), 98-105.

[36] Pophan, James W. (1987). Educational Evaluation. New Jersey: Prentice Hall Inc.

[37] Shyr, W. J., \& Chen, C. H. (2018). Designing a technology-enhanced flipped learning system to facilitate students' self-regulation and performance. Journal of Computer Assisted Learning, 34(1), 53-62.

[38] Slavin, R. E. (2017). Psikologi Pendidikan: Teori dan Praktik. Diterjemahkan Marianto Samosir. Jakarta: PT. Indeks.

[39] Smith, C. M., \& Mcdonald, K. (2013). The flipped classroom for professional development: part ii. making podcasts and videos. Journal of Continuing Education in Nursing, 44(11), 486-487. 
https://doi.org/10.3928/00220124-2013102593

[40] Spector, J. M. (2012). Foundations of Educational Technology: Integrative Approaches and Interdisciplinary Perspectives. New York: Routledge.

[41] Strayer, J.F. (2012). How Learning In An Inverted Classroom Influences Cooperation, Innovation And Task Orientation. Learning Environ Res, 15 (1), 171-193.

[42] Suhartono, I.N. S. Degeng, I. Suyitno, \& Sulton. (2019). A Comparison Study: Effects Of The Group Investigation Model And The Direct Instruction Model Toward Science Concept Understanding. Jurnal Pendidikan IPA Indonesia (JPII), 8 (2), 185-192. DOI: 10.15294/jpii.v8i2.18135.

[43] Sun, J. C. Y., Wu, Y. T., \& Lee, W. I. (2017). The effect of the flipped classroom approach to OpenCourseWare instruction on students' self-regulation. British Journal of Educational Technology, 48(3), 713-729.

[44] Tulbure, C. (2012). Learning Styles, Teaching Strategies and Academic Achievement in Higher Education: A Cross-Sectional Investigation. Procedia - Social and Behavioral Sciences, 33, 398-402. doi: 10.1016/org/10.1016/j.sbspro.2012.01.151
[45] Unin, Norseha, \& Bearing, Polin. (2016). Brainstorming as a Way to Approach StudentCentered Learning in the ESL Classroom. Procedia - Social and Behavioral Sciences, 224 605-612.

DOI: 10.1016/j.sbspro.2016.05.450

[46] Wahyudi, D., \& Suheri. (2020). Implementation and Evaluation of Digial Literacy: Strategies to Increase Reading Interest Elementary learners. The International Journal of High Education Scientists (IJHES), 1(1), 1-15.

[47] Yamada, M., Shimada, A., Okubo, F., Oi, M., Kojima, K., \& Ogata, H. (2017). Learning analytics of the relationships among selfregulated learning, learning behaviors, and learning performance. Research and Practice in Technology Enhanced Learning, 12(1), 13. https://doi.org/10.1186/s41039-017-0053-9.

[48] Zhou, G.Q., \& Jiang, X.F. (2014). Theoretical research and instructional design of the flipped classroom. Journal of Applied Mechanics and Materials, 543, 4312-4315. 